\title{
Cowpea mild mottle virus Infecting Soybean Crops in Northwestern Argentina
}

\author{
Irma G. Laguna, Joel D. Arneodo, Patricia Rodríguez-Pardina \& Magdalena Fiorona \\ Instituto de Fitopatología y Fisiología Vegetal, Instituto Nacional de Tecnología Agropecuaria - INTA, \\ Camino 60 Cuadras km 51ㄹ2,X5020ICA Córdoba, Argentina, e-mail:glaguna@correo.inta.gov.ar
}

(Accepted for publication on 20/01/2006)

Corresponding autor: Irma G. Laguna

\begin{abstract}
RESUMO
Cowpea mild mottle virus infectando soja no noroeste da Argentina

Relata-se a ocorrência natural do Cowpea mild mottle virus (CPMMV, gênero Carlavirus) em culturas de soja

[Glycine $\max (\mathrm{L}$.) Merr.] na província de Salta (noroeste argentino).
\end{abstract}

Argentina is one of the leading soybean producing and exporting countries in the world. During the 2004/2005 cropping season, soybean production reached a record 38.3 million tons. Although soybean is grown mainly in the central Pampas, it is also cultivated in the northwest of the country, where it plays a significant role in the local economy. Among the biotic factors affecting soybean yields in this region, fungal diseases account for the major economic losses (Wrather et al., Plant Dis. 81:107. 1997). Nevertheless, diseases of viral etiology have also been recorded. Six different virus species have been detected infecting soybean in Argentina: Soybean mosaic virus (SMV), Alfalfa mosaic virus (AMV), Tobacco streak virus (TSV), Cucumber mosaic virus (CMV), Peanut mottle virus (PMV) and a geminivirus which has not been characterized yet. A survey conducted in Salta Province (NW Argentina) during late summer 2005 revealed the presence of soybean plants with systemic leaf chlorosis, distortion and stunting, which were negative in serological or hybridization tests to the viruses mentioned above. This work reports on the identification of the disease's causal agent.

Leaf dip preparations were made from leaves of symptomatic and asymptomatic (presumably healthy) soybean plants. Samples were ground in phosphate buffer $\mathrm{pH} 7+0.01 \%(\mathrm{w} / \mathrm{v})$ sodium sulphite, stained with $2 \%$ uranyl acetate and examined under a JEOL 1220 electron microscope. Straight filamentous particles of about 630-650 $\mathrm{nm}$, which resembled those of carlavirus, were consistently associated with the diseased plants, while no particles were observed in samples from asymptomatic soybeans. On this basis, plants were tested for Cowpea mild mottle virus (CPMMV, genus Carlavirus) by DAS-ELISA. Leaf samples were ground in extraction buffer (PBS pH $6.8+0.05 \%$ Tween $20+2 \%$ polyvinyl pyrrolidone) at a $1: 5(\mathrm{w} / \mathrm{v})$ dilution. Specific polyclonal antisera (DSMZ GmbH, Germany) were used. Positive (supplied by DSMZ) and negative (healthy soybean) controls were included on each microtitre plate. After incubation with p-nitrophenyl phosphate at room temperature for $1 \mathrm{~h}, \mathrm{~A}_{405 \mathrm{~nm}}$ values greater than 0.900 were obtained for the infected samples, compared with less than 0.100 for the healthy controls.

CPMMV, a virus serologically unrelated to any other member of the genus, was first reported infecting Vigna unguiculata (L.) Walp. in Ghana (Brunt \& Kenten, Ann. Appl. Biol. 74:67. 1973). Natural hosts of CPMMV include several species in the family Fabaceae. Its occurrence on soybean has been reported in southeast Asia, India and west Africa (Suryawanshi et al., Indian J. Virol. 5:129. 1989). More recently, a disease causing stem necrosis of soybean in Brazil has also been attributed to CPMMV or a related carlavirus (Almeida et al., Fitopatol. Bras. 30:191. 2005). In Argentina, CPMMV has already been found on common bean (Phaseolus vulgaris L.) in Salta Province (RodríguezPardina et al., Australas. Plant Pathol. 33:129. 2004), where large populations of the whitefly vector Bemisia tabaci Genn. may be responsible for the transmission of the pathogen to other crops. The possible spread of CPMMV to different soybean production regions, as well as its economic impact, still has to be determined. 